UDC 504.45:556

DOI https://doi.org/10.32846/2306-9716-2019-1-24-2-1

\title{
MODELLING OF PROCESS OF ADSORPTION AT WASTEWATER TREATMENT FROM PHENOL
}

\author{
Hrebeniuk T.V., Dychko A.O., Bronytskyi V.O. \\ National Technical University of Ukraine \\ "Igor Sikorsky Kyiv Polytechnic Institute" \\ Peremohy prosp. 37, 03056, Kyiv \\ t.hrebeniuk07@gmail.com \\ aodi@ukr.net \\ vadim.bronytskyy@gmail.com
}

\begin{abstract}
Features of process of an adsorption at sewage treatment are considered. Features of accounting of sorption properties of sorption materials are analyzed. The simulation of the dynamics of adsorption in a fixed layer of the sorbent - activated carbon based on the equations of material balance. Key words: adsorption, sorbent, phenol, mathematical model, substance.
\end{abstract}

Моделювання процесу адсорбції під час очищення стічних вод від фенолу. Гребенюк Т.В., Дичко А.О., Броницький В.О. Розглянуто особливості процесу адсорбції під час очищення стічних вод. Проаналізовано особливості врахування сорбційних властивостей сорбційних матеріалів. Проведено моделювання динаміки адсорбції в нерухомому шарі сорбенту - активованому вугіллі - на основі рівнянь матеріального балансу. Ключові слова: адсорбція, сорбент, фенол, математична модель, речовина.

Моделирование процесса адсорбции при очистке сточных вод от фенола. Гребенюк Т.В., Дичко А.О., Броницкий В.О. Рассмотрены особенности процесса адсорбции при очистке сточных вод. Проанализированы особенности учета сорбционных свойств сорбционных материалов. Проведено моделирование динамики адсорбции в неподвижном слое сорбента - активированном угле на основе уравнений материального баланса. Ключевые слова: адсорбция, сорбент, фенол, математическая модель, вещество.

Statement of a problem. At modern rates of development of industrial production there is more and more relevant a problem of cleaning superficial and sewage. One of the highly toxic pollutants getting to reservoirs and waterways with sewage of the chemical and petrochemical companies is phenol (maximum allowable concentration is $0.001 \mathrm{mg} / \mathrm{dm}^{3}$ ). Dumping the phenol wastewater in reservoirs and waterways sharply worsens their general sanitary state, having negative impact on live organisms, not only the high toxicity, but also a significant change in the mode of consumption of biogenous elements and the dissolved gases $\left(\mathrm{O}_{2}, \mathrm{CO}_{2}\right)$.

The most effective method of sewage treatment from phenol, is adsorption of the last by means of activated carbon, but a shortcoming is the high cost and need of regeneration.

On the basis of considered, the special relevance is acquired by the works directed to receiving and a research of adsorptive properties of cheap and available materials on the basis of waste of natural origin, productions for purification of phenol wastewater.

Analysis of the last researches and publications. In this direction there is a number of publications of domestic and foreign authors, however information on a research of sorption properties of the sorbents of plant origin widespread in Ukraine in literature are absent.

In work [1] process of adsorption of phenol at sewage treatment of the pharmatsevtichny enterprise is described. As adsorbent usually use activated carbon. The optimum size of particles of adsorbent is $1.5-5 \mathrm{~mm}$. If more fine grains, then liquid filtration resistance increases. The filtering speed depends on concentration of the dissolved substances and fluctuates from 2-4 up to 5-6 $\mathrm{m}^{3} / \mathrm{h}$ through $1 \mathrm{~m}^{2}$ of cross section of a column. Water in a column moves from below up, filling all its section. To avoid adsorbent clogging waste water should not contain the solid weighed impurity.

As a sorbent the slime formed at a stage of the chemical water purification (CWP) at the pharmaceutical enterprise as a result of processes of coagulation and lime application was used. The dried-up slime has humidity of $3 \%$, rather uniform in particle size distribution, has high porosity that is especially important when using its sorption properties in the filtration mode. The low cost of CWP slime, availability allow to exclude its regeneration. At the same time its utilization by burning together 
with auxiliary fuel of the station is obviously possible.

Therefore extent of cleaning is necessary it is reached with the minimum expenses, and utilization by burning allows to receive additional amount of heat for needs of the enterprise.

The sorbent layer which is filled up in the industrial device which is a system with difficult character. As the main advantages of adsorptive installations - simplicity of instrumentation and depth of cleaning, they have to provide implementation of various requirements of a chemical engineering for effective implementation of process in this connection broad application is found by methods of mathematical modeling. Types of mathematical models are defined by specific conditions of implementation of process in the chosen equipment [2].

In work [3] process of isothermal equilibrium adsorption in dynamic conditions when filtering waste water through an adsorbent layer is considered.

The purpose of modeling is definition of optimal conditions of course of process, management of it on the basis of a mathematical model and transfer of results on an object. The full mathematical model includes the description of communications between the main variables of process in the set modes (static model) and in time upon transition from one mode to another (dynamic model).

Statement of the basic to materials. The solution of this model consists in the choice of the corresponding equations for the description of an operating mode, check of restrictions for input and output parameters, calculations of criterion function. To varied input parameters the particle size distribution of slime, filter-bed height belong. Non-variable input parameters of process are the adsorptive slurry tank, quality of initial water, the set productivity and extent of cleaning.

As regeneration in this technological process is not provided, the solution of mathematical model consists in selection of the corresponding equations for the description of an operating mode. According to duration full the cycle filter in the adsorber will coincide with adsorption time $\tau[4]$.

$$
\tau=\frac{\mathrm{G}\left(\mathrm{y}_{2}-\mathrm{y}_{1}\right)}{\omega_{0} \mathrm{~S} \rho_{\mathrm{c} . \mathrm{B}}\left(\mathrm{C}_{1}-\mathrm{C}_{2}\right)},
$$

where $\omega_{0}$ - the fictitious speed of waste water, $\mathrm{m} / \mathrm{s}$; $\mathrm{S}$ - cross-sectional area of the adsorber, $\mathrm{m}^{2} ; \rho \mathrm{c}$. century - density of waste water, $\mathrm{kg} / \mathrm{m}^{3} ; \mathrm{C}_{1}$ and $\mathrm{C}_{2}$ - concentration of the absorbed phenols in waste water, $\mathrm{mg} / \mathrm{dm}^{3}$; $\mathrm{G}$ - the mass of slime in a filter-bed.

On experimental data it is possible to receive the value of quantity of $G$ adsorbed in time $\tau$ impurity $G$ $(\tau)$ or speed of adsorption of $\mathrm{dG} / \mathrm{d} \tau$, calculated by the equation (1).

The description of dynamics of adsorption is carried out usually taking into account only one or two kinetic parameters: effective longitudinal diffusion, a mass transfer from a liquid stream to granules of adsorbent, diffusion in adsorbent granules. Calculation of mathe- matical model taking into account all specified kinetic processes is a difficult task.

For a possibility of further calculation for the equations of mathematical model of sorption cleaning in an explicit form we will accept well-known in such cases the assumption:

1. Change of density of a stream of waste water owing to reduction of an adsorbtiv can be neglected;

2. The movement of a stream in the filter is carried out in one direction with a constant speed.

3. The flow of waste water through the filter will be considered as a pseudo-binary mixture consisting of water and phenols.

4. The sorption layer is considered a continuous porous body with isomorphic properties.

5. Existence of one component in sewage leads to decrease in size of sorption of other components. Components with percentage less than $0.1 \%$ are not considered.

In this case dynamics of adsorption is described by the equations of material balance of the adsorbed substance between firm and liquid phases, kinetics of process of transfer of impurity of a liquid stream in grains of adsorbent and an isotherm of adsorption [4].

Let's assume that the stream of phenolic waste water moves with a linear speed along an adsorbent layer, at first it is not filled with the adsorbed impurity. Then the overall material balance, describes adsorption process, will register in the form of the nonlinear differential equation in separate derivatives:

$$
\frac{\partial a}{\partial \tau}+w \frac{\partial c}{\partial h}+\varepsilon \frac{\partial c}{\partial \tau}-D^{*} \frac{\partial^{2} c}{\partial h^{2}}=0,
$$

where $a$ is the value of adsorption, $\mathrm{g} / \mathrm{g}, c$ is the current concentration of the adsorptive in the stream, $\mathrm{mg} / \mathrm{dm}^{3} ; \tau$ - time, $\mathrm{s} ; w$ - velocity of the fluid flow, $\mathrm{m} / \mathrm{s}$; $h$ is the height of the layer of adsorbent, $\mathrm{cm}$; $\varepsilon$ is the porosity of the sorbent; $\mathrm{D}^{*}$ is the longitudinal diffusion coefficient taking into account molecular diffusion and convective mixing along the layer, $\mathrm{m}^{2} / \mathrm{s}$.

This equation describes balance of the adsorbed substance between firm and liquid phases. The first member of the equation reflects the number of the pollution coming to the adsorptive filter, the second - the delayed pollution, the third - the number of pollution, there was in a filtrate, the fourth - longitudinal diffusion. However at water purification in adsorbers with a dense bed of the granulated sorbent longitudinal diffusion is insignificant and it is possible with sufficient degree of accuracy to describe the mode of the movement of oily waste water in such adsorber model of ideal replacement, and within a sorbent granule - model of ideal mixture.

The equation of kinetics of process of adsorption is written in the form of [5]:

$$
\frac{\partial a}{\partial \tau}=\beta_{i}\left(c-c^{*}\right),
$$

where $\beta_{i}$ - volume coefficient of a mass transfer, $\mathrm{c}^{-1} ; \mathrm{c}^{*}$ - concentration of an adsorbtiv on an interface 
of phases, equilibrium to the current size of adsorption, $\mathrm{mg} / \mathrm{dm}^{3}$.

The differential equations of a mass exchange in a granular layer are solved taking into account entry and boundary conditions. Distribution of concentration and temperatures in initial timepoint [5]:

$$
\tau=0 ; 0 \leq h \leq L ; a=0 ; T=T_{0}=\text { const. }
$$

The boundary conditions for $\mathrm{h}=0$ are written as:

$$
\tau>0 ; c=c_{0}=\text { const } ; a=a(\tau) ; T=\text { const. }
$$

Thus, during the entire process, a stream of liquid enters the layer at a constant concentration of the adsorptive and temperature.

The adsorption isotherm is the main characteristic of the adsorbent. The adsorption isotherm equation is written as [6]:

$$
a=f(c) .
$$

On height of the working layers, it is possible to calculate mass transfer coefficient for each timepoint on the following equation:

$$
\beta_{i}=\frac{a_{i+1}-a_{i}}{C_{i+1}-C_{i}} \frac{10^{-3}}{\tau_{i}} .
$$

The coefficient of a mass transfer is influenced by the nature of sorbate and a sorbent, porosity of a sorbent; it monotonously decreases at increase in size of adsorption and the size of granules of a sorbent. The concentration of impurity in water is lower, the more probably hit in purified water is only difficult sorbed components (fig. 1) [5].

From figure 1 it is visible that the smallest discrepancy between experimental and reference points data are reached at approximation by a polynom of the $3^{\text {rd }}$ order.

Thus, the mass transfer coefficient determined by the equation (5) $\beta_{i}$ will be a variable which instant values are different in different timepoints. The nature of a curve corresponds to literary data on studying of change of coefficient of a mass transfer at adsorption. The coef-

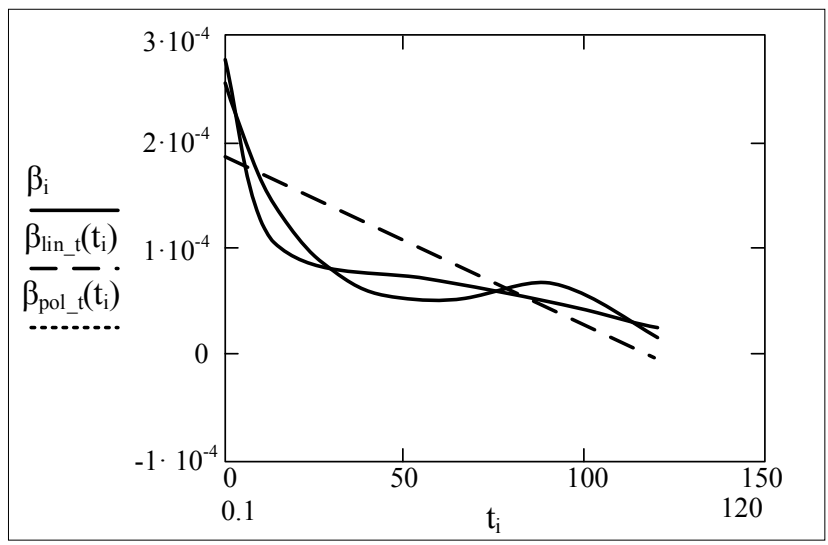

Figure 1. Mass transfer coefficient: $\beta_{i}$-experimental curve; $\beta_{\text {lin_t }}$ - linear approximation; $\beta_{\text {pol_t_t }}$-approximation by a polynom of the $3^{\text {rd }}$ order

ficient of a mass transfer can be interpreted as response function of hydrodynamic model on the corresponding perturbation.

Solution of a system of differential equations (2) (4) is finding of target function. When calculating a material balance of process of adsorption in each differential element of a layer (a grid node) of a sorbent - activated carbon taking into account kinetics of absorption of phenols the surface is formed of drain waters reflects concentration change, both in a layer, and in time.

Conclusions. Mathematical models of process of adsorption at wastewater treatment from phenol on the example of use of activated carbon are considered and analyzed.

In the course of performance of experiments from adsorption kinetics information basis allows to model dynamics of adsorption in a motionless layer of a sorbent - activated carbon on the basis of the equations of material balance in separate derivatives and the subsequent approximation with use of the built-in functions of various computing programs.

\section{Reference}

1. Лаптев А.Г., Бородай Е.Н. Математическая модель процесса адсорбции при очистке сточных вод. Москва: «Химия», 2013. 12 c.

2. Бородай Е.Н. Математическое моделирование адсорбционного процесса очистки сточных вод от нефтепродуктов. Казань: КГТУ, 2010. $188 \mathrm{c.}$

3. Чебакова И.Б. Очистка сточных вод: учеб. пособие. Омск: Изд-во ОмГТУ, 2001. 84 с.

4. Лаптев А.Г., Сергеева Е.С. Физическое и математическое моделирование сорбционных свойств торфа для очистки воды от нефтепродуктов. Казань: «Химия и экология», 2009. 14 с.

5. Кафаров В.В., Глебов М.Б. Математическое моделирование основных процессов химических производств: учеб. пособие для вузов. Москва: «Высшая школа», 1991. 400 с.

6. Матвейкин В.Г. Математическое моделирование и управление процессом короткоцикловой безнагревной адсорбции. Москва: Издательство «Машиностроение-1», 2007. 140 с. 